Krogh, who in his private laboratory had taken up an investigation of the flight of insects. The participation in these studies led Weis-Fogh into a number of interesting problems ranging from the mechanical problems of flight, muscle- and nerve-physiology to metabolism and chemical investigations on the properties of mechanical components in the structure of the flying mechanisms. After Krogh's death in 1949, Weis-Fogh acted as head of Krogh's private laboratory until 1953 (supported by the Anti-Locust Research Centre, London). During 1953-54 he joined Prof. F. Buchthal at the Neurophysiological Institute as associate lecturer in the University of Copenhagen. In 1954 his connexion with the University of Cambridge began with a visit to the Department of Zoology as Fellow of the Rockefeller Foundation. From 1956 he was Balfour Student of the University of Cambridge and member of Trinity College, but in 1958 he was asked to return to Copenhagen to be professor in zoophysiology and head of the Zoophysiological Laboratory $B$ of the University of Copenhagen. In 1961 he acted as Prather lecturer in biology in Harvard University. He is a Fellow of the Royal Danish Academy of Sciences and Letters and of the Danish Academy of Technical Sciences.

The professorship in Copenhagen was a research professorship with no formal teaching duties, and the work of Weis-Fogh and his collaborators in the years since 1959 has resulted in a series of important papers on many subjects, among which may be mentioned the co-ordination of motor activity in flight, diffusion problems, tracheal respiration and a number of papers on a peculiar rubber-like protein, resilin, found in the locust cuticle. Though Weis-Fogh considers research his main activity, his general interest in the development of Danish science forced him to spend time and energy on organization problems. He has been in the forefront of the fight for re-organization of the University of Copenhagen and of the structure of Danish science. He will be missed in Denmark not only as an inspiring scientist but also as an organizer and teacher of advanced students. While regretting his departure from Denmark, his colleagues wish him success in his new position and hope that it will lead to a strengthening of the ties between British and Danish science.

\section{Mechanical Engineering in the Massachusetts Institute of Technology : \\ Prof. A. H. Shapiro}

Prof. Ascher H. Shapiro, well known for his work on fluid dynamics and a leader in revising and improving engineering education in the United States, has been appointed head of the Department of Mechanical Engineering at the Massachusetts Institute of Technology. $\mathrm{H}_{\Theta}$ has been on the teaching staff of the Institute for twentyfive years. He succeeds Dr. H. Guyford Stever, who has been appointed president of the Carnegie Institute of Technology in Pittsburgh. Emeritus Prof. C. Richard Soderberg has been acting head of the Department pending the appointment of a permanent successor to Prof. Stever. Prof. Stever also was head of the Institute's Department of Naval Architecture and Marine Engineering. Prof. Soderberg has also been acting head of this Department on an interim basis and he will continue in this capacity until a successor to Dr. Stever is appointed. Prof. Shapiro is at present ehairman of the Faculty of the Massachusetts Institute of Technology. Prof. Shapiro has received international recognition in recent years for his development of motion-picture films as a significant component of engineering education. $\mathrm{He}$ was founder and first chairman of the National Committee for Fluid Mechanics Films, which, under sponsorship of the U.S. National Science Foundation, is producing films which have already been so influential as to have inspired similar efforts in other areas of engineering education. He is at present chairman of the Committee on Educational Films of the Commission on Engineering Education.
His research and professional activities for industry and Government have been principally related to the engineering problems of power production and propulsion engines. During the Second World War, he directed for the Navy Bureau of Ordnance a laboratory charged with the development of torpedo engines. He was a member of the Lexington Project which in 1948 evaluated the technical feasibility of nuclear-powered aircraft, in the course of which he invented a new form of nuclear-aircraft-propulsion system. In 1953, he directed "Project Dynamo", which evaluated for the Atomic Energy Commission the technology and economics of nuclear power for civilian use and which predicted the competitive economic position which nuclear power is assuming to-day. In the area of Government service, he has been a member of advisory groups to the National Advisory Committee for Aeronautics, and to the Office of the Secretary of Defence, and he is at present a member of the Scientific Advisory Board of the U.S. Air Force.

\section{Physics in the University of Saskatchewan :}

Prof. L. Katz

Prof. Leon Katz, professor of physics and director of the Linear Electron Accelerator Laboratory at the University of Saskatchewan, Saskatoon, has been appointed head of the Physics Department at that University. $\mathrm{He}$ succeeds Dr. R. N. H. Haslam, who was appointed dean of arts and science at the University in 1964, and who is resigning the headship in physics to devote more time to his duties as dean. Dr. Katz has been with the University of Saskatchewan since 1946. He is best known for the part he played in establishing on the Saskatoon campus the recently opened linear accelerator laboratory, which is Canada's newest and largest laboratory for nuclear research. Besides extensive research in the field of nuclear physics, Dr. Katz has also conducted. investigations in thermodynamics, micro-wave spectroscopy, and the ratio of specific heats of gases. Before joining the University of Saskatchewan, Dr. Katz was an engineer in the Electronics and Electro-Mechanical Division of the Westinghouse Electric Manufacturing Co., Pittsburgh. Dr. Katz was born in Poland, but when he was quite young his family emigrated to Canada and he attended public and high school in Toronto. He gained B.S. and M.S. degrees from Queen's University, Kingston, and was awarded a Ph.D. by the California Institute of Technology. Dr. Katz is a Fellow of the Royal Society of Canada, a Fellow of the American Physical Society, a member and past president of the Canadian Association of Physicists, and a member of the Physical Society (Great Britain). He was chairman of the Canadian Association of Physicists Committee set up to acquire a high-energy machine for Canada.

\section{Marine Nuclear Propulsion}

IN a written answer in the House of Commons on July 7, Mr. F. Cousins, the Minister of Technology, stated that at June 30 about 95 qualified scientists and engineers were engaged on research and development on marine nuclear propulsion within his Department, including the Atomic Energy Authority and the Ship Research Association. This figure compared with 140 in 1964,180 in 1963 , 95 in 1962,55 in 1961 and 30 in 1960. The cost of research

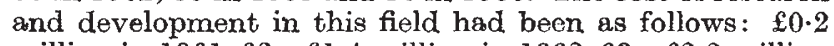
million in $1961-62 ; £ 1.4$ million in $1962-63 ; £ 2.2$ million in $1963-64 ; £ 2.0$ million in $1964-65 ; £ 0.3$ million in the first quarter of 1965-66.

\section{Grants to University Students}

IN a written answer in the House of Commons on July 2, Mr. A. Crosland, the Secretary of State for Education and Science, stated that total expenditure on grants to university students in England and Wales, by the Scottish Education Department and under the 